\title{
Nutrient and Phytoplankton Dynamics along the Ocean Road Sewage Discharge Channel, Dar es Salaam, Tanzania
}

\author{
Mariam I. Hamisi ${ }^{1}$ and Florence A. Mamboya ${ }^{2}$ \\ ${ }^{1}$ College of Natural and Mathematical Sciences, University of Dodoma, P.O. Box 259, Dodoma, Tanzania \\ ${ }^{2}$ Dar es Salaam Institute of Technology, Department of Science and Laboratory Technology, P.O. Box 2958, Dar es Salaam, Tanzania \\ Correspondence should be addressed to Mariam I. Hamisi; mhamis2005@yahoo.co.uk
}

Received 6 February 2014; Revised 21 April 2014; Accepted 22 April 2014; Published 4 June 2014

Academic Editor: Winn-Jung Huang

Copyright (c) 2014 M. I. Hamisi and F. A. Mamboya. This is an open access article distributed under the Creative Commons Attribution License, which permits unrestricted use, distribution, and reproduction in any medium, provided the original work is properly cited.

\begin{abstract}
Ocean Road shoreline is situated close to Dar es Salaam largest fish market and is subjected to sewage discharge. In this study, temporal and spatial variations of physicochemical parameters and phytoplankton were studied in five stations along the Ocean Road Coast. Phytoplankton composition, temperature, dissolved oxygen (DO), salinity, water clarity, $\mathrm{pH}$, and dissolved inorganic nutrients (DIN) including nitrite, nitrate, and phosphate were measured. Results revealed that DIN were significantly higher in the station close to the discharge point than other stations $(P<0.0001)$. There were no significant temporal variations in DIN except nitrate that was significantly higher during Northeast Monsoon than Southeast Monsoon $(P<0.001)$. Other environmental parameters showed no significant differences except clarity, conductivity, and DO. Occurrence of potential harmful species such as Trichodesmium, Microcystis, and Pseudo-nitzschia was observed. The phytoplankton biomass (chlorophyll $a$ ) ranged from 3.2 to $56.5 \mathrm{mg} \mathrm{m}^{-3}$ and 18 to $113 \mathrm{mg} \mathrm{m}^{-3}$ for Mjimwema (MJ) and Ocean Road (OR) stations, respectively. There was significant difference $(P=0.0033)$ in chlorophyll $a$ among the stations being higher in OR II. The phytoplankton biomass was positively correlated with nutrient concentration in all stations except OR I. This study suggests an alarming level of DIN at OR that may alter phytoplankton biomass, abundance, and composition.
\end{abstract}

\section{Introduction}

Aquatic ecosystems around the world mostly have been heavily impacted by waste discharges from human activities, including point sources of urban, residential and industrial pollution, and nonpoint sources of agricultural pollution which alters the nutrient contents of the coastal waters. Traditionally, pathways of nutrient influx to the coastal water bodies were considered mainly surface river runoff and waste water discharges $[1,2]$. Increase in anthropogenic inputs has led to severe eutrophication problems, inducing an enhancement of phytoplankton primary production in many coastal areas $[3,4]$. In addition to increasing primary production, nutrients dynamics have inevitable effects on the taxonomic composition of phytoplankton communities [4]. It is known that there is a large difference between coastal ecosystems in the magnitude and character of responses of phytoplankton biomass or primary production to anthropogenic inputs (e.g., $[5,6])$. It is also known that seasonal succession of phytoplankton can be controlled by a combination of physical, chemical, and biological variables [7]. However, Reynolds [5] reported that nutrient is the major factor affecting the dynamics of phytoplankton. For instance, excessive nutrients loading can result in proliferation of the harmful phytoplankton species, the phenomena known as harmful algal blooms $[6,8]$.

Harmful algal blooms can cause fish mortality and seafood poisoning; toxins are hazardous to aquatic ecosystem as they may accumulate into aquatic organisms and transfer, in a food chain, from low trophic levels to higher trophic levels. In addition, phytoplankton bloom can limit light penetration [9-11] hence limiting photosynthesis of the benthic 
macrophytes. To develop appropriate management strategies, it appears necessary to fully understand the ecosystem functioning and first of all the relationships existing between phytoplankton and nutrient concentration patterns in aquatic ecosystems, in particular along the coastal areas.

In Tanzania, Ocean Road is an example of coastal area receiving a lot of pollutants from the Dar es Salaam port and sewage from the major sewer pipe which drains the city center and some industrial areas. Despite the fact that this area is located very close to the fish landing site and local communities use the seawater to process their fish, little has been studied to establish the phytoplankton composition and levels of nutrients. Limited studies related to nutrients have been conducted in this area and mainly focused on determination of heavy metal pollutants [12-15]. In addition, only baseline information of phytoplankton exists in Tanzanian coast as shown in [16-22], with limited information for Ocean Road area. Therefore, this study aimed at establishing levels of inorganic nutrients and phytoplankton dynamics in Ocean Road and Mjimwema focusing on safeguarding the health status of the ecosystems and communities that depend on the coastal resources in that area.

\section{Materials and Methods}

2.1. Study Sites. This study was conducted during 2008-2009, along the coastal area of Dar es Salaam at $6^{\circ} 49^{\prime}$ S, 39 $19^{\prime}$ E and $6^{\circ} 50^{\prime} \mathrm{S}, 39^{\circ} 21^{\prime} \mathrm{E}$, Ocean Road (OR) and Mjimwema (MJ), respectively (Figure 1). OR is a place where Dar es Salaam main fish market "Ferry", Dar es Salaam port entrance, and the major Dar es Salaam sewer pipeline that drain the city center and some industrial areas are located. MJ is located south of the Ocean Road; it is regarded as pristine area as it lacks major inflows and is also protected from wave impacts by a line of islands, namely, Kendwa, Makatumbe, and Sinda as explained by Hamisi et al. [14]. Five sampling stations were established from OR towards MJ, in which three stations were established in Ocean Road (OR I, OR II, and OR III) while two stations were established in Mjimwema (MJ I and MJ II).

Ocean Road I is located close to the fish market $(\sim 300 \mathrm{~m})$ away from the mouth of the sewer pipeline (discharging point) while Ocean Road II is located $\sim 150 \mathrm{~m}$ from discharge point and Ocean Road III is located close to discharge point (less than $50 \mathrm{~m}$ ). Mjimwema stations are located away from the discharging point; MJ I is an offshore station which is located $\sim 2.0 \mathrm{~km}$ from the Ocean Road discharge point while Mjimwema II is located just close to Mjimwema Beach along the intertidal zone about $50 \mathrm{~m}$ from the beach and $\sim 3.0 \mathrm{~km}$ from the Ocean Road discharge point.

\subsection{Sample Collection, Field Measurements, and Laboratory Work}

2.2.1. Physicochemical Parameters. Sampling was conducted once per month in every site during spring low tide (during ebb flow) for a period of one year. During each field visit, the surface water temperature, dissolved oxygen (DO), salinity, turbidity, conductivity, and $\mathrm{pH}$ were measured using a multiparameter instrument (Horiba, Japan); clarity was measured using a Secchi disc. Surface water samples were collected in each station using water sampler for nutrients and chlorophyll $a$ measurements. For nutrient analyses, the subsamples were filtered through GF/F filters into a polythene bottle and stored frozen $\left(-20^{\circ} \mathrm{C}\right)$. The nutrient filtered and stored water samples were analyzed for nitrite, nitrates, and phosphates as detailed in Parsons et al. [23].

2.3. Phytoplankton Composition, Diversity, and Biomass Estimation. Samples were collected using plankton net (mesh size 20 and $80 \mu \mathrm{m}$ ) and preserved using formalin $2 \%$ together with few drops of Lugol's solution. Phytoplankton was identified to generic level followed by morphological descriptions given by various identification keys. Samples for abundance (counting) were kept in a dark glass bottle and fixed immediately with $4 \%$ formalin. Phytoplankton counting was done by counting the cells under light microscope using a sedge Rafter cell [24]. In addition, phytoplankton biomass was measured using a chlorophyll $a$ determination method; the duplicate samples of the known water volume $(0.5 \mathrm{~L})$ were filtered through GF/F, $25 \mathrm{~mm}$, and pigment extracted and analysed as explained in Parsons et al. [23].

2.4. Statistical Analysis. Environmental parameters and phytoplankton biomass were tested statistically for temporal and spatial variations; differences/variation was tested using parametric or nonparametric tests on the analysis of variance (ANOVA), Zar [25]. In cases of significant differences, postcomparison tests (Tukey Krumer or Dunn's multiple comparison tests) were applied to establish where a significant difference occurred. Cluster analysis was done to classify sampling sites for their similarity in relation to nutrients concentrations.

\section{Results}

\subsection{Environmental Parameters}

3.1.1. Concentration of Dissolved Inorganic Nutrient. Dissolved inorganic nitrite, nitrate, and phosphate were analyzed and results are presented in Figure 2; the mean values ranged from $0.15 \pm 0.01$ to $0.61 \pm 0.05 \mu \mathrm{mol} l^{-1}, 0.01 \pm 0.00$ to $5.45 \pm$ $0.04 \mu \mathrm{mol} \mathrm{l}^{-1}$, and $0.1 \pm 0.00$ to $0.78 \pm 0.05 \mu \mathrm{mol} \mathrm{l}^{-1}$ for nitrite, nitrate, and phosphate, respectively. Statistically, using the nonparametric ANOVA (Kruskal-Wallis Test) with Dunn's post-multiple comparison test showed significantly different nutrient (nitrite, nitrate, and phosphate) levels among the sampling stations $(P<0.0001)$, being significantly higher in Ocean Road III (close to discharge point) and low in Mjimwema II (away from the discharge point). The post hoc test (Dunn's multiple comparison) also showed significant variation among the stations as shown in Table 1.

Furthermore, there was no significant monthly variation in dissolved inorganic nutrient measured (ANOVA, $P>0.05)$. Considering the monsoon seasonal changes, November to April which is Northeast Monsoon (NEM) and June to October (Southeast Monsoon (SEM)), results 


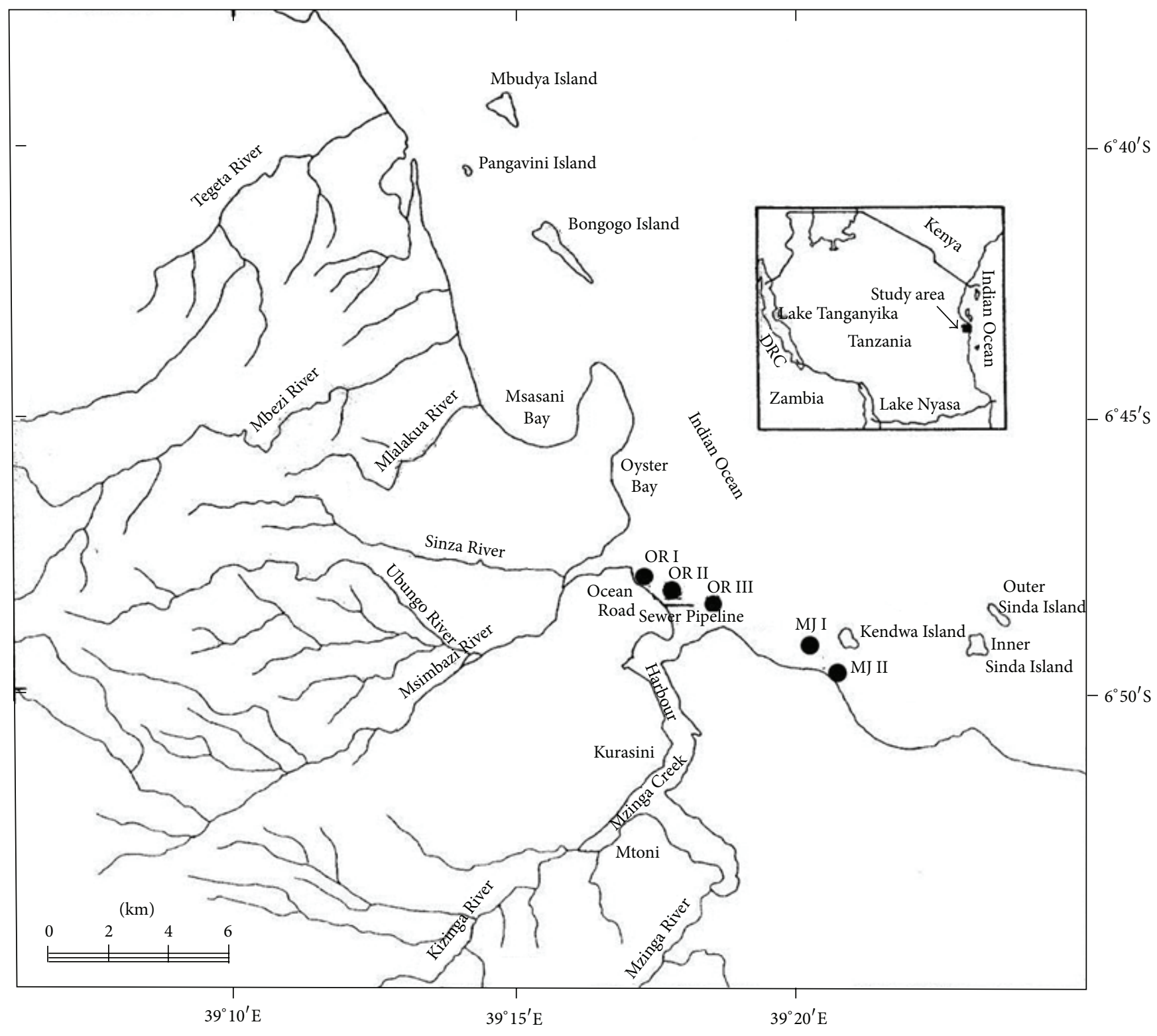

Sampling station

FIgURE 1: Map showing the study site. Note: cycles represent sampling stations.

show that nitrite and phosphate levels do not have significant differences between NEM and SEM (Wilcoxon test, $P>$ $0.05)$, while there are extremely significantly higher nitrate levels during NEM than SEM $(P<0.001)$. In relation to inorganic nutrient concentrations in different sampling stations, cluster analysis test revealed very close similarity between sampling stations MJ I and MJ II followed by OR I. The station OR III had no close similarity with other stations with regard to inorganic nutrient concentrations (Figure 3).

3.1.2. Physicochemical Parameters. The mean values of the water temperature, salinity, conductivity, $\mathrm{pH}$, dissolved oxygen, clarity, and turbidity are shown in Figure 4 . The values ranged from 7.6 to $8.6,26$ to $32^{\circ} \mathrm{C}, 0.8$ to $4 \mathrm{~m}, 30$ to $37 \%$, 42

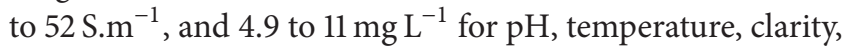

salinity, conductivity, and dissolved oxygen, respectively. Statistically, using Kruskal Wallis test, $\mathrm{pH}$, temperature, and salinity were not significantly different among the studied stations as well as with season $(P>0.05)$, while clarity, conductivity, and dissolved oxygen showed significant difference among stations as shown in Table 2 . The clarity was being higher in MJ I (less turbid) than OR II and OR III; similarly the dissolved oxygen was significantly higher in $\mathrm{MJ}$ than in OR stations.

\subsection{Phytoplankton Composition, Diversity, and Biomass}

3.2.1. Composition and Diversity. Phytoplankton diversity was analyzed throughout the study period; thirty-two phytoplankton genera were identified; among them about twenty 


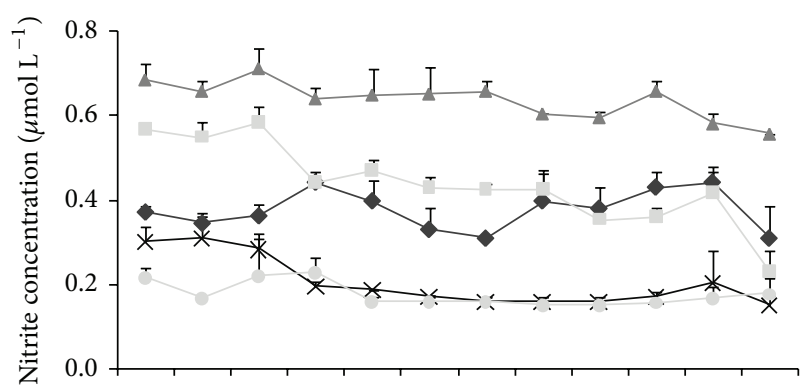

(a)

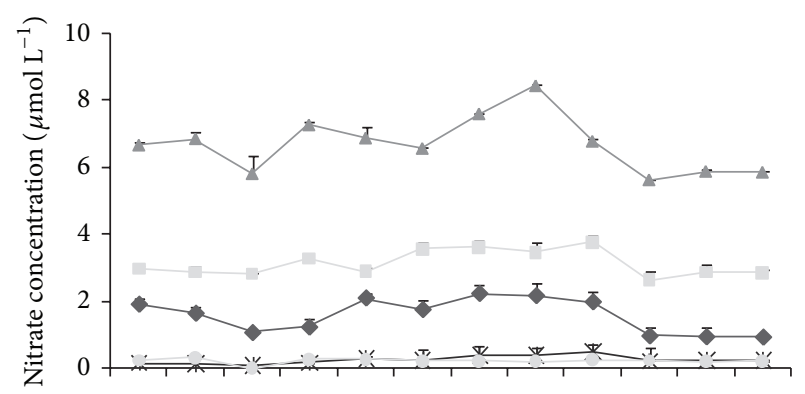

(b)

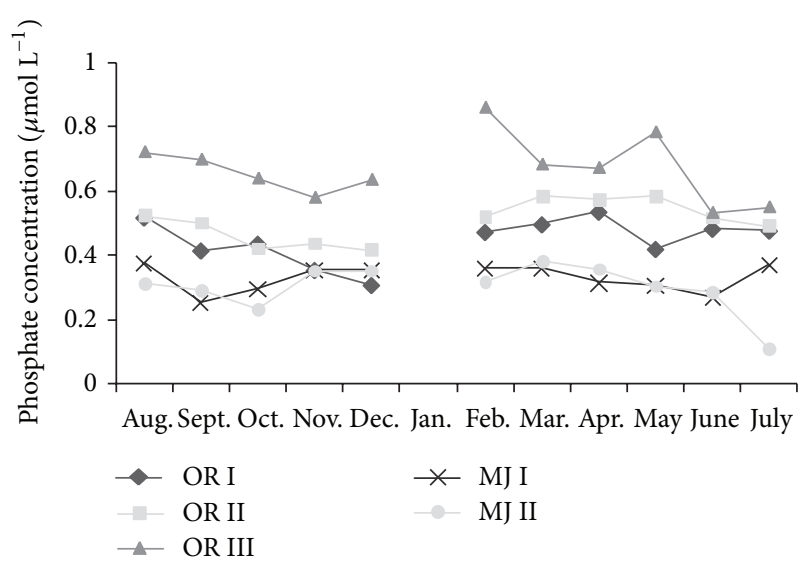

(c)

FIGURE 2: Spatial and temporal variations of the dissolved inorganic nutrient: $(\mathrm{a})=$ nitrite,$(\mathrm{b})=$ nitrate, and $(\mathrm{c})=$ phosphate.

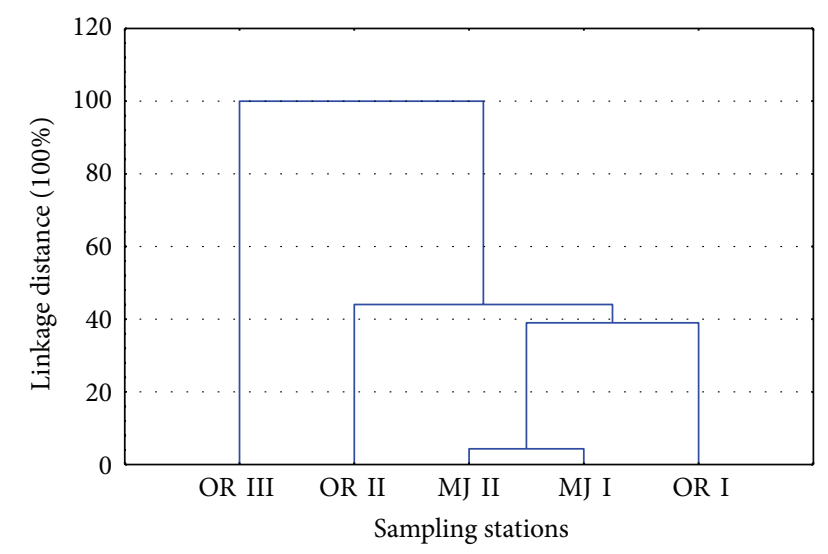

FIGURE 3: Similarity of sampling stations in relation to concentration of nutrients.
TABLE 1: Comparison of the nutrient levels among stations (Dunn's multiple comparison).

\begin{tabular}{lccc}
\hline \multirow{2}{*}{ Sites } & \multicolumn{2}{c}{ Dunn's multiple comparison test results } \\
& Nitrite $\left(\mathrm{NO}_{2}\right)$ & Nitrate $\left(\mathrm{NO}_{3}\right)$ & Phosphate $\left(\mathrm{PO}_{4}\right)$ \\
\hline OR I versus OR II & $\mathrm{Ns}$ & $* * *$ & $\mathrm{Ns}$ \\
OR I versus OR III & $* * *$ & $* * *$ & $*$ \\
OR I versus MJ I & $* * *$ & $* * *$ & $\mathrm{Ns}$ \\
OR I versus MJ II & $* * *$ & $* * *$ & $\mathrm{Ns}$ \\
OR II versus OR III & $* * *$ & $* * *$ & $\mathrm{Ns}$ \\
OR II versus MJ I & $* * *$ & $* * *$ & $* *$ \\
OR II versus MJ II & $* * *$ & $* * *$ & $* *$ \\
OR III versus MJ I & $* * *$ & $* * *$ & $* * *$ \\
OR III versus MJ II & $* * *$ & $* * *$ & $* * *$ \\
MJ I versus MJ II & $\mathrm{Ns}$ & $\mathrm{Ns}$ & $\mathrm{Ns}$
\end{tabular}

Ns: not significant; $P>0.05 ;{ }^{*}$ significant; $P<0.05 ;{ }^{* *}$ very significant; ${ }^{* * *}$ extremely significant.

TABlE 2: Comparison of the environmental parameters among stations (Dunn's multiple comparison).

\begin{tabular}{|c|c|c|c|}
\hline \multirow{2}{*}{ Sites } & \multicolumn{3}{|c|}{ Dunn's multiple comparison test results } \\
\hline & $\begin{array}{c}\text { Clarity } \\
(P=0.0001)\end{array}$ & Conductivity & $\begin{array}{c}\text { Dissolved } \\
\text { oxygen }\end{array}$ \\
\hline OR I versus OR II & $\mathrm{Na}$ & Ns & Ns \\
\hline OR I versus OR III & $\mathrm{Na}$ & * & Ns \\
\hline OR I versus MJ I & $\mathrm{Na}$ & Ns & Ns \\
\hline OR I versus MJ II & $\mathrm{Na}$ & Ns & $* * *$ \\
\hline OR II versus OR III & * & Ns & Ns \\
\hline OR II versus MJ I & $* *$ & Ns & Ns \\
\hline OR II versus MJ II & $\mathrm{Na}$ & Ns & ** \\
\hline OR III versus MJ I & $* * *$ & $* *$ & $* *$ \\
\hline OR III versus MJ II & $\mathrm{Na}$ & $*$ & $* * *$ \\
\hline MJ I versus MJ II & $\mathrm{Na}$ & Ns & Ns \\
\hline
\end{tabular}

Na: not applicable shallow sites; Ns: not significant; $P>0.05 ;{ }^{*}$ significant; $P<0.05 ;{ }^{* *}$ very significant; ${ }^{* * *}$ extremely significant.

(20) genera were diatoms, six (6) cyanobacteria, and six (6) dinoflagellates. The common diatom genera recorded were Thalassionema, Pseudo-nitzschia, Chaetoceros, Navicula, Nitzschia, Skeletonema, Licmophora, and Rhizosolenia. The cyanobacteria genera found were Lyngbya, Oscillatoria, Spirulina spp., Richelia, Trichodesmium, and Microcystins while the only dinoflagellates identified were Procentrum, Protoperidinium, Pyrophacus, Ceratium, Amphidinium, and Ornithocercus. Interestingly, during sampling in November to December 2008, Trichodesmium bloom mixing with Microcystis was found in all sites while the occurrence of the genus Spirulina was only in Ocean Road III station. However, the phytoplankton species composition was not uniform in all the stations and during the sampling time.

3.2.2. Phytoplankton Biomass. Phytoplankton biomass was measured as chlorophyll $a$ concentration; all the Ocean Road stations were found to have higher phytoplankton biomass during the whole study period (Figure 5). There 


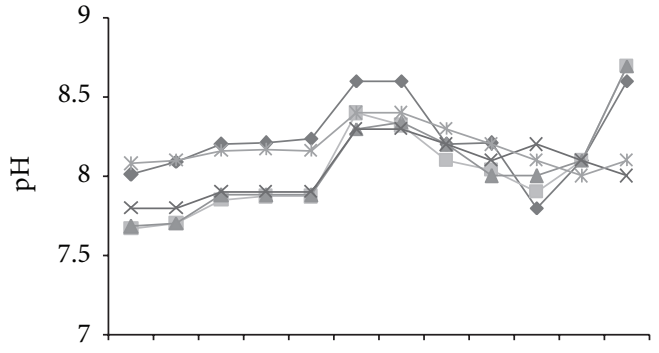

(a)

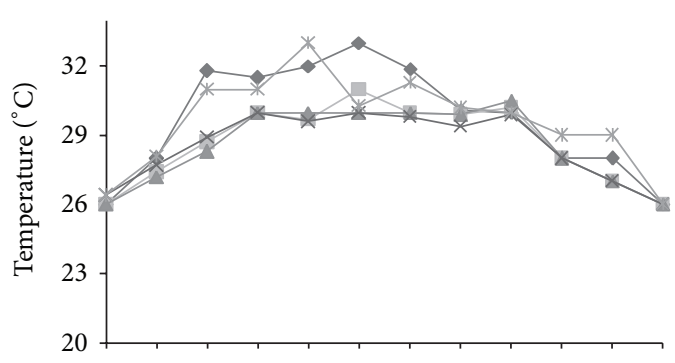

(b)

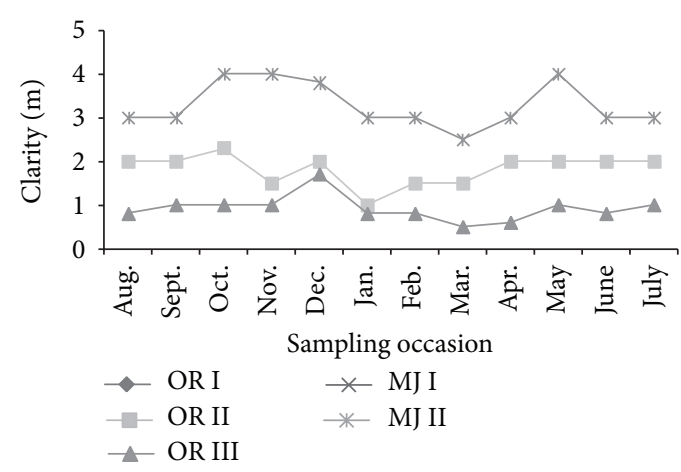

(c)

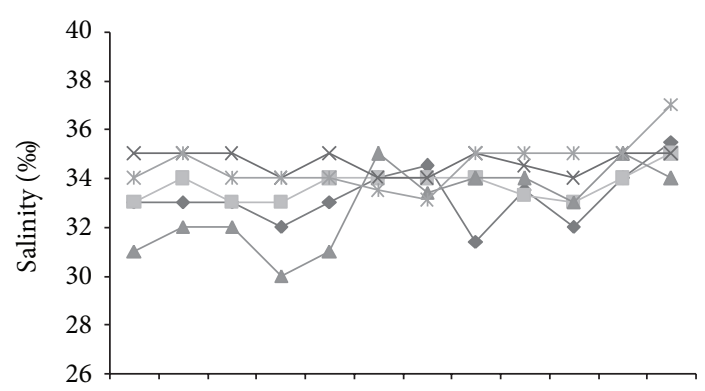

(d)

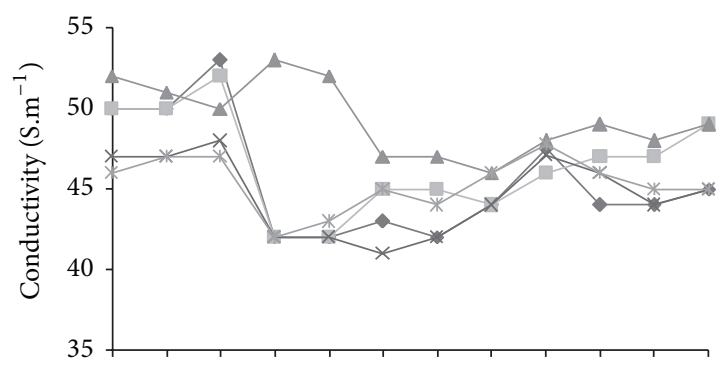

(e)

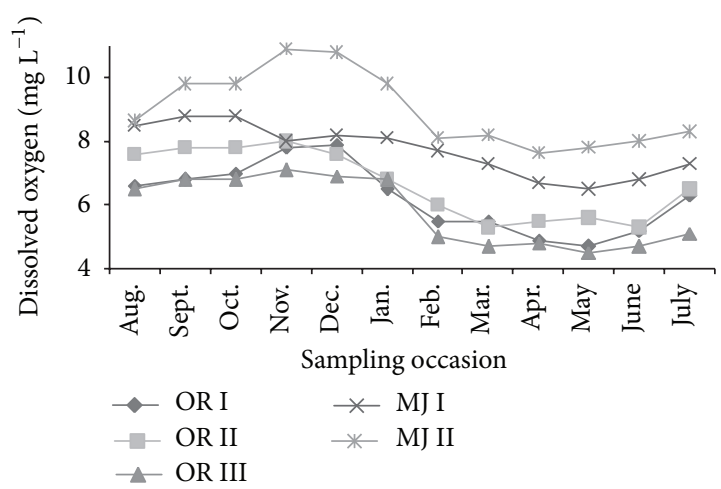

(f)

FIGURE 4: Spatial and temporal variation of the physicochemical parameters recorded during the sampling period: (a) $\mathrm{pH}$, (b) temperature, (c) clarity, (d) salinity, (e) conductivity, and (f) dissolved oxygen.

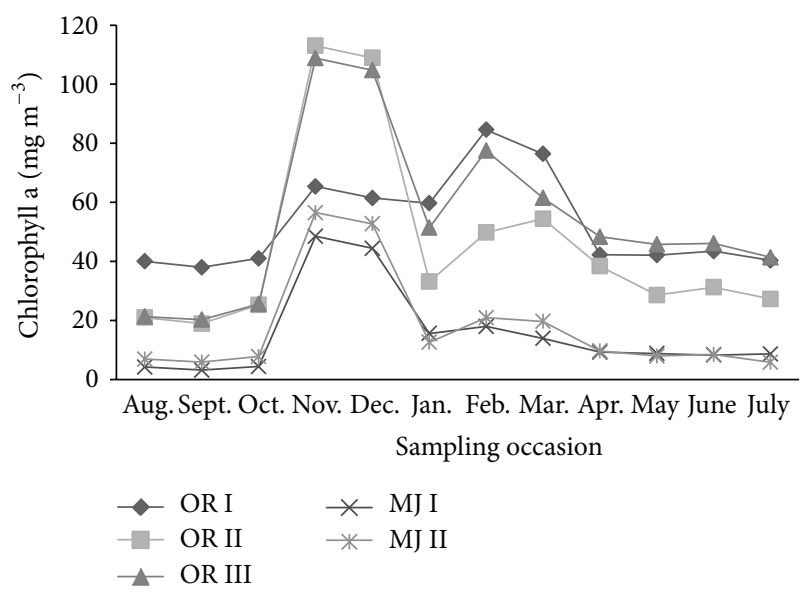

FIgURE 5: Spatial and temporal variation of phytoplankton biomass (chlorophyll $a$ ) during the study. was significant difference $(P=0.003)$ in phytoplankton biomass among the stations being higher in Ocean Road II. The post hoc test showed significant differences between OR stations and MJ stations as indicate in Table 3. There were no significant differences in phytoplankton biomass among OR or MJ stations themselves. In addition, there was significantly higher phytoplankton biomass $(P<0.0001)$ in November as compared to other periods.

The Pearson correlation test showed significant positive correlation between phytoplankton biomass ( $\mathrm{Chl} a$ ) and nutrient concentration in all stations except OR I $\left(r^{2}=0.14\right.$, $P=0.009$ for OR II, $r^{2}=0.13, P=0.01$ for OR III, $r^{2}=0.13$, $P=0.01$ for MJ I, and $r^{2}=0.13, P=0.01$ for MJ II).

\section{Discussion}

The results showed that there is a large variation of dissolved inorganic nutrient levels and other environmental 
TABLE 3: Chlorophyll “ $a$ ” post hoc statistical test (Dunn's multiple comparison) for comparisons between the sites.

\begin{tabular}{lc}
\hline Sites & Dunn's multiple comparison test \\
\hline OR I versus OR II & Ns \\
OR I versus OR III & Ns \\
OR I versus MJ I & $* *$ \\
OR I versus MJ II & $* *$ \\
OR II versus OR III & Ns \\
OR II versus MJ I & Ns \\
OR II versus MJ II & Ns \\
OR III versus MJ I & $* *$ \\
OR III versus MJ II & $* *$ \\
MJ I versus MJ II & Ns \\
\hline
\end{tabular}

Ns: not significant; $P>0.05 ;{ }^{*}$ significant; $P<0.05 ;{ }^{* *}$ very significant; *** extremely significant.

parameters among the stations; the levels are high close to the mouth of the sewer pipeline and decrease towards Mjimwema sampling stations. This observation might have been contributed by the sewage effluents discharged at Ocean Road, hence proposing that the sewage effluents may have great contribution to the physicochemical and biological properties including phytoplankton composition in this area. However, location and distance from the discharge point have been seen as very important factors controlling the nutrient levels as well as the phytoplankton dynamics. For instance, Mjimwema being a sheltered beach in which waves and currents are protected by the line of discontinuous islands on either side Mlay et al. [26], the flow of nutrient rich water from the discharge point has been largely reduced, hence low nutrient levels and phytoplankton biomass as compared to Ocean Road.

The mean nutrient levels reported in this study are higher compared to other studies done along the Western Indian Ocean region in the environment with the same influences $[14,27,28]$. For instance, the highest values recorded in Zanzibar Island at Chapwani were 3.2 and $0.22 \mu \mathrm{M}$ for total nitrogen and phosphate, respectively [28]. Chapwani is known to have high inputs of sewage discharged from Zanzibar town, similar environment as Ocean Road. The higher nutrient levels in the current study could be attributed to the presence of the highly sewage contaminated water at OR stations in particular at OR III, in which the nitrate and phosphate concentration ranged from 6.68 to $0.67 \mu \mathrm{moll}^{-1}$ throughout the study period. The higher nutrient levels provide "early warning" indicators of increasing pollution to this area and its vicinity including the fish landing site, the situation that poses a threat to marine ecosystems, and health of communities. Higher nitrate levels recorded in NEM than SEM during the study period could be due to increasing runoff into the ocean, as it is well known that NEM is associated with long and heavy rain season $[14,17]$.

The observed high phytoplankton biomass in OR stations is attributed to the increasing nutrient levels as it has been shown in this study that the nutrient concentration positively correlated with phytoplankton biomass. Moreover, this increasing nutrient load may result in the occurrence of toxic species, such as the Microcystis and Pseudo-nitzschia, as observed during November-December. The genus Microcystis is known to produce hepatotoxin known as microcystin $[29,30]$ as well as the genus Pseudo-nitzschia [31, 32]. The occurrence of toxic species provides another point of concern, as increasing pollution may cause massive growth "bloom" which may pose a health risk to beach users including fish sellers and consumers. Furthermore, the occurrence of Spirulina in OR stations is likely to be influenced by the increase in nutrient, as it has been previously reported that Spirulina spp. occur in environments with higher nutrient levels and varying temperature and salinity [33]. Thus, the presence of Spirulina spp. in OR stations is likely to be influenced by the higher nutrient levels, particularly nitrate and phosphate, as a result of sewage discharge.

Other environmental parameters apart from nutrient showed variations among the stations under study, hence proposing differences in the water quality. For example, the wide variation in dissolved oxygen (DO) showed that the station with low DO was more contaminated, as the area receives more organic matter. It is clear that more oxygen is used for decomposition of organic matter, a microbial process, thus low DO. Therefore, higher nutrient levels and low DO at OR as compared to MJ stations suggest the existence of eutrophic condition along the Ocean Road coastal waters. In addition, the low water clarity in OR stations showed that the effluent brings the particulate organic matter to the OR coastal waters which in turn affect water clarity by increasing turbidity of the water column. This might have significant impacts on the phytoplankton and benthic community as phenomena can hinder light penetration and hence may result in change in phytoplankton composition and biomass.

\section{Conclusion and Recommendations}

This study demonstrates that Ocean Road coastal waters have higher levels of dissolved inorganic nutrient which in turn affect the qualitative and quantitative phytoplankton composition. The main sewer pipeline that drains the Dar es Salaam city center is the cause of the observed higher nutrient levels in Ocean Road. Furthermore, the presence of potential toxic phytoplankton species may pose a health risk to varying marine, coastal, and terrestrial species including human beings. This information is useful to provide "early warning" indicators of the Ocean Road coastal pollution, for better management and monitoring of the healthy ecosystems. There is a need to develop more safe ways for extending the sewage system inward to the sea to allow quick dilution or treatment of sewage before discharging into the sea. Equally important is a periodical and more detailed study which is necessary to investigate the presence of toxic phytoplankton species in that area to safeguard the health of the coastal ecosystems and communities as a whole.

\section{Conflict of Interests}

The authors declare that there is no conflict of interests regarding the publication of this paper. 


\section{Acknowledgments}

The authors would like to express their sincere gratitude to Western Indian Ocean Marine Science Association (WIOMSA) through Marine Research Grant I (MARG I) for funding this research. The authors are grateful to Mr. Mhonda Y. P., Mr. Ramadhani S.I., Mr. Kapenya, and Mr. Usipime for assistance during field work.

\section{References}

[1] A. Henriksen and D. O. Henssen, "Whole catchment studies on nitrogen cycling: nitrogen from mountains to fjords," Ambio, vol. 26, pp. 254-257, 1997.

[2] D. O. Henssen, A. Hinder, and G. Holtan, "The significance of nitrogen runoff for eutrophications of freshwaters and marine recipients," Ambio, vol. 26, pp. 312-320, 1997.

[3] E. H. Kinney and C. T. Roman, "Response of primary producers to nutrient enrichment in a shallow estuary," Marine Ecology Progress Series, vol. 163, pp. 89-98, 1998.

[4] J. E. Cloern, "Our evolving conceptual model of the coastal eutrophication problem," Marine Ecology Progress Series, vol. 210, pp. 223-253, 2001.

[5] C. S. Reynolds, The Ecology of Freshwater Phytoplankton, Cambridge University Press, Cambridge, UK, 1984.

[6] D. M. Anderson, J. M. Burkholder, W. P. Cochlan et al., "Harmful algal blooms and eutrophication: examining linkages from selected coastal regions of the United States," Harmful Algae, vol. 8, no. 1, pp. 39-53, 2008.

[7] U. Sommer, Z. M. Gliwicz, W. Lampert, and A. Duncan, "The PEG-model of seasonal succession of planktonic events in fresh waters," Archiv für Hydrobiologie, vol. 106, pp. 433-471, 1986.

[8] H. W. Paerl, "Coastal eutrophication and harmful algal blooms: importance of atmospheric deposition and groundwater as "new" nitrogen and other nutrient sources," Limnology and Oceanography, vol. 42, no. 5, pp. 1154-1165, 1998.

[9] R. B. Domingues, A. Barbosa, and H. Galvão, "Nutrients, light and phytoplankton succession in a temperate estuary (the Guadiana, south-western Iberia)," Estuarine, Coastal and Shelf Science, vol. 64, no. 2-3, pp. 249-260, 2005.

[10] L. Zhai, C. Tang, T. Platt, and S. Sathyendranath, "Ocean response to attenuation of visible light by phytoplankton in the Gulf of St. Lawrence," Journal of Marine Systems, vol. 88, no. 2, pp. 285-297, 2011.

[11] M. L. Richlen, S. L. Morton, E. A. Jamali, A. Rajan, and D. M. Anderson, "The catastrophic 2008-2009 red tide in the Arabian gulf region, with observations on the identification and phylogeny of the fish-killing dinoflagellate Cochlodinium polykrikoides," Harmful Algae, vol. 9, no. 2, pp. 163-172, 2010.

[12] J. F. Machiwa, "Anthropogenic pollution in the Dar es Salaam harbour area, Tanzania," Marine Pollution Bulletin, vol. 24, no. 11, pp. 562-567, 1992.

[13] J. F. Machiwa, "Heavy metals and organic pollutants in sediments of Dar es Salaam harbour prior to dredging in 1999," Tanzania Journal of Science, vol. 26, pp. 29-46, 2000.

[14] M. I. Hamisi, T. J. Lyimo, and M. H. S. Muruke, "Cyanobacterial occurrence and diversity in seagrass meadows in Coastal Tanzania," Western Indian Ocean Journal of Marine Science, vol. 3, pp. 113-122, 2004.

[15] F. A. Mamboya, Heavy metals contamination and toxicity, Studies of Macroalgae from the Tanzanian coast [Ph.D. thesis], Botany Department, Stockholm University, 2007.
[16] I. Bryceson, An ecological study of the phytoplankton of the coastal waters of Dar es Salaam [Ph.D. thesis], University of Dar es Salaam, 1977.

[17] I. Bryceson, "Seasonality of oceanographic conditions and phytoplankton in Dar es Salaam waters," University Science Journal, vol. 8, no. 1, pp. 66-76, 1982.

[18] T. J. Lyimo, Role played by phytoplankton cyanobacteria with an emphasis on Trichodesmium species in increasing nitrogen level in the near shore waters of Tanzania [M.S. thesis], University of Dar es Salaam, 1995.

[19] C. Lugomela, Autecology of the Toxic Dinoflagellate Gambierdiscus toxicus Adachi et Fukuyo (Dinophyceae) in Central Coastal Areas of Tanzania, 2006.

[20] C. Lugomela, "Noctiluca scintillans (Dinophyceae) in central coastal waters of Tanzania: a new phytoplankton record in the area," Western Indian Ocean Journal of Marine Science, vol. 6, pp. 117-124, 2007.

[21] M. Kyewalyanga and C. Lugomela, "Existence of potentially harmful microalgae in coastal waters around Zanzibar: a need of monitoring programme?" in Marine Science Development in Tanzania and East Africa. Proceedings of the 20th Anniversary Conference on Advances in Marine Sciences in Tanzania. 28th June-1st July 1999, D. M. Richmond and J. Francis, Eds., pp. 319327, IMS/WIOMSA, Zanzibar, Tanzania, 2001.

[22] C. Lugomela, T. J. Lyimo, I. Bryceson, A. K. Semesi, and B. Bergman, "Trichodesmium in coastal waters of Tanzania: diversity, seasonality, nitrogen and carbon fixation," Hydrobiologia, vol. 477, no. 1-3, pp. 1-13, 2002.

[23] R. T. Parsons, Y. Maita, and C. M. Lalli, A Manual of Chemical and Biological Methods for Seawater Analysis, Pergamon Press, Oxford, UK, 1989.

[24] W. J. Woelkerling, R. R. Kowal, and S. B. Gough, "Sedgwickrafter cell counts: a procedural analysis," Hydrobiologia, vol. 48, no. 2, pp. 95-107, 1976.

[25] J. H. Zar, Biostatistical Analysis, Prentice Hall, Inc, Englewood cliffs, NJ, USA, 4th edition, 1999.

[26] A. P. Mlay, G. M. Wagner, and Y. D. Mgaya, "A comparative study of the ecology of four sandy/muddy shores in the Dar es Salaam area," in Marine Science Development in Tanzania and Eastern Africa. Proceedings of the 20th Anniversary Conference on Advances in Marine Science in Tanzania. 28 June-1 July 1999, M. D. Richmond and J. Francis, Eds., pp. 375-399, IMS/WIOMSA, Zanzibar, Tanzania, 2001.

[27] M. S. Mohammed and Y. D. Mgaya, "Nutrients and their dynamics in the coral reefs off Zanzibar town," in Marine Science Development in Tanzania and Eastern Africa. Proceedings of the 20th Anniversary Conference on Advances in Marine Sciences in Tanzania. Institute of Marine Sciences, University of Dar es Salaam and Western Indian Ocean Marine Science Association, M. Richmond and J. Francis, Eds., pp. 171-183, Zanzibar, Tanzania, 2001.

[28] J. Uku and M. Björk, "Productivity aspects of three tropical seagrass species in areas of different nutrient levels in Kenya," Estuarine, Coastal and Shelf Science, vol. 63, no. 3, pp. 407-420, 2005.

[29] R. J. Wicks and P. G. Thiel, "Environmental factors affecting the production of peptide toxins in floating scums of the cyanobacterium Microcystis aeruginosa in a hypertrophic African reservoir," Environmental Science and Technology, vol. 24, no. 9, pp. 1413-1418, 1990.

[30] A. J. Van der Westhuizen and J. N. Eloff, "Effect of temperature and light on the toxicity and growth of the bluegreen alga 
Microcystis aeruginosa," Z. Pflanzenphysiol, vol. 110, pp. 157-163, 1985.

[31] C. A. Scholin, F. Gulland, G. J. Doucette et al., "Mortality of sea lions along the central California coast linked to a toxic diatom bloom," Nature, vol. 403, no. 6765, pp. 80-84, 2000.

[32] F. M. D. Gulland, M. Haulena, D. Fauquier et al., "Domoic acid toxicity in Californian sea lions (Zalophus californianus): Clinical signs, treatment and survival," Veterinary Record, vol. 150, no. 15, pp. 475-480, 2002.

[33] A. Vonshak and L. Tomaselli, "Arthrospila (Spirulina): systematics and ecophysiology," in The Ecology of Cyanobacteria, Their Diversity in Time and Space, A. B. Whitton and M. Potts, Eds., pp. 502-522, Kluwer Academic, 2000. 

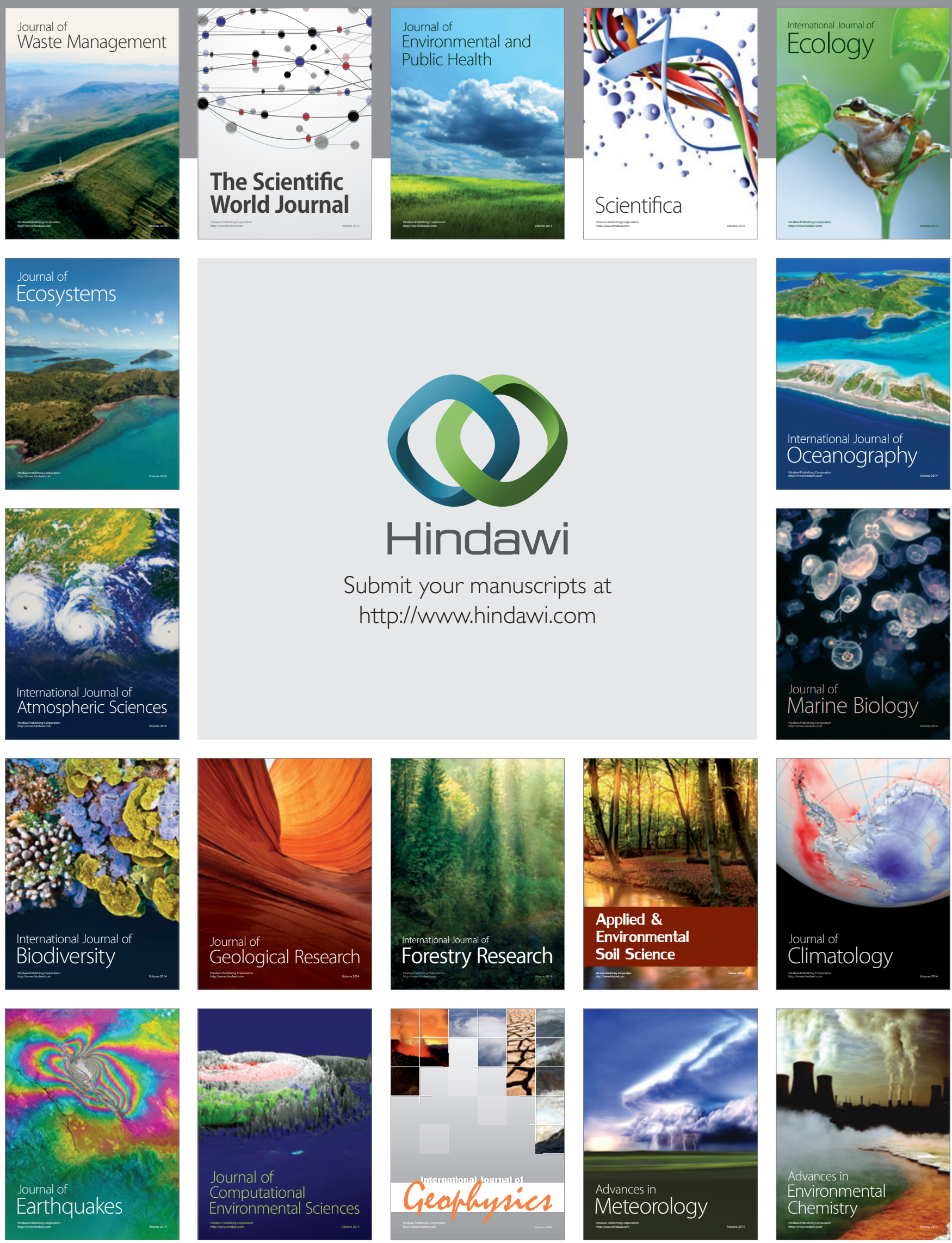